\title{
Dias estranhos: publicidade e espetáculo
}

\author{
Marta de Araújo Pinheiro
}

\section{Resumo}

A publicidade é hoje um dispositivo de experimentações que coloca impasses para a cultura contemporânea. Ao ter como propósito deixar no usuário/consumidor uma sensação que deverá ser lembrada a qualquer momento, ela se reapropria do espetáculo no sentido de que ele envolve 0 espectador. A hipótese é de que esse novo uso da linguagem não é só devido aos desafios provocados pelas novas interfaces, pelo excesso de informação e pela cultura digital acelerada e dispersa. Ele é também devido às solicitações da sociedade pós-industrial que cria zonas indiscerníveis entre cotidiano e espetáculo, experiência e ilusão. Palavras-chave

Publicidade. Espetáculo. Experiência. Cultura.
Marta de Araújo Pinheiro I martapinheiro@uol.com.br

Universidade Federal de Juiz de Fora. Professora do Programa de Pós-Graduação em Comunicação e Sociedade da UFJF e Professora Associada da Escola de Comunicação da UFRJ.

Este texto é uma versão modificada do trabalho com o mesmo título apresentado na XVIII Encontro da Compós, em junho de 2009.

\section{Introdução}

A Pepsico lançou o Toddy Ice, quarto

achocolatado da marca, voltado aos adolescentes

e, em vez de novo sabor, inaugurou o conceito

de experiência na marca: deixar na garganta a

sensação de frescor.

A vitrine de um banco de investimentos é tomada por hologramas de jogadores de futebol que interagem com pessoas que passam pela rua; em certa cidade, um flash mob irrompe no asfalto deixando todos que aí circulam estupefatos, logo adiante, formando com os participantes uma imagem da garrafa de coca-cola; em Barcelona, uma instalação montada com dois carros "gêmeos" desvia os olhares dos passantes da Feira de Modas 2009 para uma determinada marca de roupas...

0 convite a experimentar e deixar uma sensação a ser lembrada é 0 apelo destas mensagens que usam linguagens de games, flash mob, ambientes holográficos, intervenções urbanas. 0 que se está vendendo é inicialmente secundário achocolatado, refrigerantes, investimentos, moda -, pois o proposto é atrair um público flutuante 
para uma experiência, e não diretamente para um produto ou serviço. Não se busca coagir: é um convite espetacular e instantâneo para o qual as pessoas são atraídas.

0 que a publicidade estaria dizendo sobre a contemporaneidade quando se torna, assim como demais propostas estéticas atuais, um veículo de experimentações? A hipótese é de que a forma de atuação proposta por esses usos da linguagem publicitária não é unicamente devida ao desafio da apropriação das novas interfaces que envolvem práticas mais lúdicas e imersivas e da dispersão do interesse do consumidor entre tantos estímulos que hoje ele recebe. Mais do que isso, ao envolver pessoas em uma experiência, a publicidade busca atrair atenção, participação e envolvimento como imperativos de conectividade que criam zonas quase indiscerníveis entre cotidiano e espetáculo, realidade e ilusão, arte e publicidade visando integrar vida e mercado.

A partir do conceito de dispositivo, o objetivo é explorar - no sentido de que se está mais próximo de um mecanismo de formação - a publicidade enquanto um dos instrumentos da tecnocultura contemporânea na produção de novos modos de subjetivação aptos à experiência de conectividade.

Tucherman e Saint-Clair (2008) consideram que o conceito de dispositivo operado por Michel Foucault é muitas vezes tomado apressadamente na área de comunicação como sinônimo de "aparato tecnológico". Segundo os autores, esse conceito é "[...] bastante complexo, capaz de introduzir perspectivas teóricas no debate acerca das tecnologias comunicacionais em seu contexto histórico-cultural" (2008, p. 2). Como ferramenta metodológica, eles consideram esse conceito profícuo por considerar as tecnologias de comunicação como sendo mais um elemento de " um todo heterogêneo e movente com discursos, instituições, saberes e práticas diversas" (2008, p. 4) e não como um aparato previamente dado que determinaria efeitos sócio-culturais.

Foucault busca pelo termo dispositivo demarcar: a) a rede que se forma entre 0 dito e 0 não dito do conjunto heterogêneo que engloba discursos, instituições, organizações arquitetônicas, regulamentos, leis, enunciados; b) a natureza da relação entre estes elementos heterogêneos; c) um tipo de formação que, em determinado momento histórico, responde a uma urgência e, nesse sentido, possui uma função estratégica dominante (FOUCAULT, 1982, p. 244-245).

Compreende-se a publicidade, portanto, não como campo de saber específico, e sim como um possível dispositivo formado por agrupamento de elementos heterogêneos em uma rede comum. Dispositivo que também pode ser entendido como "combinação de práticas específicas condutora dos seres humanos em complexos conjuntos de visão, ação e julgamento, que visa à retórica da escolha e à ética da autonomia, características dos modos de subjetivação contemporâneos" (RABINOW; ROSE, 2003, p. XI). Somando-se 
essa conceituação de dispositivo à anterior, a publicidade seria um "instrumento prático e intelectual" que permite identificar o papel da tecnocultura na produção de subjetividade.

No decorrer deste artigo, no "panorama", buscase mapear indicadores (ditos e não ditos) que constituiriam um dispositivo; no "espetáculo", ensaia-se a relação entre esses indicadores sob a égide do espetáculo; na conclusão, avançase sobre uma possível urgência estratégica da publicidade na contemporaneidade.

\section{Panorama}

0 que dizer de um trilhão de páginas únicas na Internet no ano de 2008? ${ }^{1}$ Uma sobrecarga de informações formada pela enorme quantidade de inovações tecnológicas e comunicativas em relação à capacidade de absorção do consumidor ou do público.

Esse excesso convive com a sensibilidade de modos de subjetivação liberais², que convida à escolha e à autonomia associadas ao aumento da capacidade de compartilhamento das experiências, dada a ampliação das redes de sociabilidade e de informaçã $0^{3}$. As novas linguagens e a interação proporcionadas pelas condições tecnológicas conduzem ao desenvolvimento de uma dinâmica perceptiva - baseada na manipulação de formas e de informações que utilizam o tato, a visão, a audição - que origina novos padrões perceptivos, sensitivos, e modos de socialização, à distância, em redes, globais. Neste panorama de mudanças, as noções de público e de consumidor ${ }^{4}$ adquiriram um novo sentido, no qual sensibilidades, interesses e perfis são temporários e flexíveis, continuamente desfeitos e refeitos.

Além das mudanças tecnológicas e midiáticas, os meios de produção agora são técnicas e procedimentos de comunicação e informação. 0 conhecimento passa a ser a força produtiva e ele resulta da cultura coletiva compartilhada por trocas comunicativas. A comunicação é 0 elemento central pelo qual o trabalhador cria significados e relações sociais ao manipular

Dados obtidos no googleblog.blogspot.com em julho de 2008.

Nas sociedades liberais avançadas, segundo Nikolas Rose, governa-se através de escolhas reguladas de cidadãos, agora constituídos como sujeitos de escolhas e com aspirações de auto-realização. Os indivíduos modernos não são meramente obrigados a escolher, mas obrigados a escolher para compreender e conduzir suas vidas. (1996, p. 41; 1999, p. 87)

Sobre as transformações e deslocamentos na comunicação relacionados às redes sociais e de informação, ver Pinheiro (2006).

Para Philip Kotler (1998), o público é qualquer grupo que tenha interesse real ou potencial ou que cause impacto na capacidade da empresa de atingir seus objetivos. Kotler apresenta sete tipos de públicos: público financeiro; público da mídia; público do governo; público de defesa do consumidor; público local; e o público geral. 0 público-alvo é um segmento do público de interesse sobre o qual o profissional de comunicação vai atuar para resolver ou prevenir um problema. Na visão de marketing, esse público pode constituir-se de consumidores atuais ou potenciais, de pessoas que decidem a compra ou, ainda, das que a influenciam. Pode ser composto de indivíduos, grupos, públicos particulares, ou do público em geral. 0 público-alvo afetará fortemente as decisões do comunicador sobre 0 que será dito, como será dito, quando será dito, onde será dito e quem irá dizê-lo. 
símbolos e imagens, fazendo com que produção e consumo alimentem um ao outro ${ }^{5}$.

Diferentemente das mercadorias fordistas ${ }^{6}$, cujo consumo implica seu desgaste, o consumo do conhecimento, da informação, dos serviços não os esgota, pelo contrário, o consumo destes bens chamados imateriais passa a ser um fator importante na atividade criadora requisitada para a produção. Um livro como objeto pode ter seu desgaste físico dado ao manuseio, porém aquilo que ele oferece no ato de leitura, o que é imaterial ${ }^{7}$ (não mensurável), pode ser alimento para o desenvolvimento de outros processos reprodutivos ou inovadores. Esses bens "imateriais" têm sua circulação e sua distribuição como elementos fundamentais. Caso esses bens ficassem estocados e limitados em sua circulação, eles impossibilitariam a interlocução entre 0 produtor e 0 usuário/consumidor, o que impediria o compartilhamento da cultura, da informação, dos saberes e da ciência. Compartilhamento esse que capacita a sociedade fixar metas comuns.

No chamado capitalismo $\operatorname{cognitivo}{ }^{8}$, as atividades subjetivas são mobilizadas para comunicar, informar, dialogar, julgar ou avaliar. Elas exigem tempo e, ao mesmo tempo, estão à mercê da contingência, de uma situação de trabalho dado, de um problema específico que precisa ser colocado onde ele ainda não existe: 0 conhecimento novo é produzido no acontecimento a partir do conhecimento compartilhado. Em vez de princípios tayloristas de planificação e de prescrição de tarefas, cabe ao indivíduo o esforço de conhecimento e de concepção para definir e organizar os meios de suas próprias ações. Portanto, indivíduos passam a estar sempre imersos em situações precárias (não se está mais em um emprego e sim com um "job") nas quais o significado de ser livre é ser flexível e estar apto a fazer de si mesmo uma experiência concreta de mobilização contínua da vontade, do físico, da inteligência e das sensações.

Esse modelo solicita que os indivíduos se expressem e cooperem criativamente. Para tal, uma "produção de si" passa a ser uma exigência em que, ao invés da passividade, a "liberdade" é necessária para que um intérprete ativo narre suas mudanças e crie seus perfis em uma intensa e incessante mobilização individual e coletiva.

Sobre o papel da comunicação no pós-fordismo, ver Marazzi (2002).

A vida de uma mercadoria fordista típica era de cinco a sete anos, mas o novo modelo de acumulação diminui esse tempo em mais da metade em certos setores (como têxtil e vestuário), enquanto outros, por exemplo, videogames e programas de computador, a meia vida cai para períodos cada vez menores (HARVEY, 1993, p. 148).

Sobre economia do imaterial, ver Gorz (2005).

Também chamado de Economia do Conhecimento, o capitalismo cognitivo revê modelos da teoria econômica e tem as novas tecnologias de comunicação e informação como a base de uma sociedade pós-industrial, na qual o valor decorre da difusão acelerada e a socialização do saber. 
Como resultados, a cultura e a experiência de si são mercadorias e mediadas pelo dispositivo retroalimentador da publicidade. Elas são expostas como recursos pelos meios de comunicação e de informação de modo que os consumidores possam absorvê-las, transformá-las, ao mesmo tempo em que transformam a si próprios, devolvendo 0 resultado dessas experiências como novas commodities para o mercado. ${ }^{9}$

\section{Experiências}

Em "Estranhos prazeres" (Strange Days), filme de ficção científica de 1995, a ação se passa nos últimos dias de 1999, véspera do fim do milênio. Na cidade de Los Angeles, filmada em clima futurista pré-Matrix associado ao das revoltas sociais ali recentemente ocorridas, um ex-tira (Ralph Fiennes) é um viciado que negocia uma droga proibida por lei: pequenos discos digitais contendo gravações de ondas cerebrais de experiências vividas por pessoas. Os usuários das tais drogas se viciam nas emoções e memórias dos outros e buscam cada vez mais novas experiências alheias. Quando o ex-tira vivencia, e não mais se esquece, a experiência de morte da sua namorada enquanto ela é assassinada, ele vive uma experiência que fará com que saia de sua imobilidade e se envolva a partir daí em uma trama policial que coloca em xeque alguns limites: 0 que qualifica uma experiência como real ou ilusória? 0 que define uma experiência pessoal? Como estes limites são demarcáveis?

É também de 1995 o livro "The experience economy", que coloca a experiência como o novo gênero de valor econômico diferente dos bens e dos serviços. A experiência ocorre quando a empresa usa intencionalmente serviços como sendo um palco para engajar os consumidores individualmente e proporcionar acontecimentos que não devem ser esquecidos. Segundo os autores, as commodities são fungíveis, os bens tangíveis, os serviços intangíveis, e as experiências memoráveis (PINE II; GILMORE, 1995, p.98). As experiências seriam produtos diferentes dos serviços (bens intangíveis), pois se paga para passar o tempo desfrutando um acontecimento que deverá ficar marcado pelas sensações e ser então rememorado. Elas são pessoais e existem somente na mente de cada indivíduo que precisa estar de algum modo envolvido, seja em nível emocional, físico, intelectual ou espiritual.

Promover experiências sempre fez parte dos negócios de entretenimento - como a Disney - e este conceito se alastrou para teatros, parques, museus, bares temáticos, lojas com aromas, esportes radicais. As novas mídias e tecnologias também encorajam novos gêneros de experiência, tais como jogos interativos e imagens que 
simulam situações de imersão. Cada experiência deriva da interação entre 0 que é performatizado e 0 estado do indivíduo no período, e 0 valor dessa mercadoria está associado à riqueza das sensações e memórias geradas. Em resumo, a função econômica da experiência é ser um palco; a natureza de sua oferta é ser memorável; seu principal atributo é ser pessoal; seu método de reposição é a duração; seu consumidor é um convidado e seu fator da demanda é a sensação.

Filme e livro são signos possíveis de serem traçados de uma máquina que, quase muda e cega, faz ver e falar não as leis abstratas de uma economia global e sim as micro-operações de interação que respondem à urgência de se promover conexões entre vida cotidiana e mercado, e entre afeto, memória e valor. É nesta configuração em que se ensejam novos modos de sentir que a publicidade também se coloca como um dispositivo.

\section{Publicidade}

A publicidade é um campo que sempre se situou na interseção de vários saberes. 0 fetichismo da mercadoria, pela problematização do marxismo; como máquina de desejo, numa análise freudiana; como entendimento dos modos de vida, pela sociologia; e análise de texto e de imagem, pelos estudos da semiologia, da semiótica e da retórica.

Essas abordagens se tornam insuficientes quando isoladas no momento no qual a publicidade se insere em práticas midiáticas sofisticadas e modos de ser complexos. Ela hoje penetra não só diversos ambientes da sociedade como também passa a criá-los fazendo a fusão entre ambientes midiáticos e vida cotidiana, tornando cada vez mais opaca a distinção entre produção material e mensagem promocional; entre produtor e consumidor (prosumidor); e entre produtor, consumidor e usuário (produsuário) ${ }^{10}$. Também na sociedade pós-disciplinar, a economia do poder faz o desejo reencontrar o desejo de ser localizado, o que faz a publicidade ser uma ação sobre variáveis não previamente determinadas e cada vez mais sujeita ao acaso dos acontecimentos.

Numa visada histórica, em seu momento inicial, fins do século XIX, com a industrialização e 0 transporte de massas, os produtos produzidos em série na fábrica fordista eram identificados,

Segundo Axel Bruns (2008), prosumidores (prosumers) foi o termo originalmente concebido por Alvin Toffler, em seu livro "The third wave" (1980), para identificar um novo tipo de consumidor engajado no processo de produção de significados e ativo no compartilhamento de valores. Já o termo produsuário (produser) significa um empoderamento do usuário: ao possuir o controle das ferramentas de comunicação e ao construir comunidades em redes, o usuário de ambientes colaborativos se compromete tanto como consumidor quanto como produtor de conteúdo, sendo que muitas vezes assume os dois papéis. Para 0 autor, o prosumer de Toffler seria simplesmente um consumidor mais ativo cujo feedback de suas necessidades, gostos e impressões permite a criação de novos produtos e serviços pelas empresas, mas que ainda manteria um forma tradicional hierárquica de gerenciamento e produção, pois ouvir as preferências e investir nelas é para o próprio ganho da empresa. Já no novo paradigma das redes, onde circulam os produsers, produtores e usuários de conteúdo da mídia, são simples nós em uma rede neutra que se comunicam em iguais condições. 
via publicidade, com marcas associadas às circunstâncias e às pessoas familiares do cotidiano (Dr. Kelloggs, Tia Benta), aproximando 0 consumidor do produto agora feito longe de sua casa (KLEIN, 2003). A partir da metade do século XX, as marcas não eram mais associadas aos produtos e sim aos conceitos, identificando os consumidores com uma subjetividade idealizada ("não vendo carros, mas um conceito de mobilidade"). Hoje, diante de tantos estímulos, quando os produtos são informações, conhecimento, sensações, a publicidade ainda busca criar laços e identificações em torno das marcas em uma sociedade na qual a nova mídia exclui a possibilidade de criar padrões uniformes de reconhecimento ou de produzir conceitos comuns, dadas a pulverização do consumidor e a dinâmica da economia global.

Nesse novo cenário, uma das estratégias para se manter a substância do valor de uma marca - que é o que fica na mente de um consumidor (KELLER, 2001, 14) - é integrar dimensões pessoais e vida cotidiana à marca, fazendo com que os consumidores "trabalhem a marca", como no marketing viral, na interação nas redes sociais, no boca a boca. Um outro modo tem sido a construção de um lugar onde os consumidores possam interagir e compartilhar uma "experiência de marca", como o Espaço Hermès em Tóquio. Uma outra é exemplarmente demonstrada no comercial "Life's for sharing", da T-mobile, que mobilizou por celular, em maio de 2009, na Trafalgar Square, em Londres, mais de 13 mil pessoas de idades, gêneros, etnias e nacionalidades diferentes para cantarem juntas a canção Hey Jude, dos Beatles, diante de um telão de karaokê, onde também podiam se ver e ser vistas ao vivo. 0 filme pode ser acessado no Youtube e certamente foi uma performance que será para sempre lembrada por aqueles que dela participaram. É interessante observar que não se vê no filme (nos seus diversos formatos) referências ao celular ou à sua marca. Convidadas a participar, as pessoas eram ao mesmo tempo atores e plateia, agentes e receptores, produtores e consumidores de um comercial. Elas estavam ali juntas, vivendo um acontecimento, em nome de causa alguma, a não ser 0 da sensação de ali poderem experimentar uma outra ordem de exaltação, o espetáculo de um dia qualquer na Trafalgar Square, no qual todos podiam se ver lado a lado ou nas telas.

Não se trata, portanto, somente de interagir com uma "experiência de marca" ${ }^{11}$. É viver

Experiência de marca ou brand experience são respostas internas e subjetivas do consumidor (sensações, sentimentos e cognições) e comportamentais evocadas por estímulos relacionados a uma marca (design, identidade, ambiente, comunicação). Meios pelos quais a marca se cria na mente de um consumidor e que algumas experiências são controladas, como no caso da publicidade, nos produtos e serviços, em websites, etc. Outras não, como ocorre nos comentários jornalísticos e no boca a boca. Ver também verbete "brand experience": The cumulative brand impressions garnered from visual, verbal and experiential encounters with the brand. The brand experience encompasses a range of intellectual, sensory and emotional connections. Disponível em: < www.texastech.edu/identityguidelines/glossary.php $>$. Acesso em: $13 \mathrm{dez} .2008$. 
uma outra ordem de experiência junto com outras pessoas que fazem do cotidiano e das ruas um ato de espetáculo. Ao promoverem a participação ativa dos indivíduos que optam por estar ali, espetáculo e publicidade formam um dispositivo. Quais necessidades e urgências ele busca atender na contemporaneidade? A espetacularização da sociedade, da cultura, da arte, da comunicação vem sendo tematizada e criticada como aquilo que brilha porque cega desde 0 início da modernidade, principalmente por pensadores como Walter Benjamin, Theodor Adorno e Guy Debord. Será o dispositivo publicitário contemporâneo pensável sob esta mesma contradição moderna?

\section{Espetáculo}

Entre os diversos projetos apresentados na $1^{a}$ Exposição Internacional de Londres, em 1851, o Palácio de Cristal era apresentado como o único edifício do mundo cujo ambiente seria perceptível a um espectador situado em qualquer lugar, da extremidade oriental ou ocidental; mesmo as partes mais distantes do edifício apareceriam, segundo seus projetistas, envolvidas em um "halo azul". Para Agamben (1990), este seria o primeiro grande triunfo da mercadoria sobre 0 espaço. Uma contradição "espetacular" era aí anunciada: ao mesmo tempo em que o público deveria responder com uma concepção grandiosa que abalaria a sua imaginação, pois lhe era requisitado um olhar feérico, deveria manter um olhar reconhecedor de produtos parecidos e uniformemente agrupados lado a lado.

\section{Walter Benjamin também caracteriza a}

Modernidade por uma contradição espetacular que seria a experiência do choque, visto que toda experiência do homem do século XIX aparece à luz da impossibilidade de uma experiência autêntica, pois a ele só eram destinadas as vivências: "Pois qual 0 valor de todo o nosso patrimônio cultural, se a experiência não mais o vincula a nós?" (BENJAMIN, 1985, p. 115). A Exposição Universal de Paris, em 1855, é considerada por Benjamin como a primeira grande exposição da mercadoria a ser contemplada por um público espectador. Além de apresentarem seu valor econômico, as mercadorias tinham também 0 valor de sonho. Nesse sentido, elas adquiriam um caráter de espetáculo em que a imagem é separada do objeto e se dirige ao público para encantá-lo.

As Galerias de Paris, para Benjamin, formavam passagens desorientadoras que oflâneur transformava em espetáculos. Eram templos do capital que expunham as mercadorias ao olhar dos passantes, tornando-se espaços onde o sonho se unia ao novo modo de produção. As passagens seriam as moradas do sonho e da fantasmagoria da mercadoria, na qual o caráter do sonho aparece desvinculado dos mecanismos de sua realização.

Adorno e Horkheimer (1985), no mundo pós Segunda-Guerra Mundial, mostravam que a 
racionalidade técnica do capitalismo moderno tinha a indústria cultural como aquela que passava toda a experiência humana ao seu princípio e, deste modo, o mundo se tornava 0 prolongamento daquela indústria. Quanto mais a Indústria Cultural oferecesse uma reprodução da realidade em seus espetáculos, mais o mundo exterior seria visto como uma extensão deles. Ao consumir os produtos da indústria cultural, 0 trabalhador adaptava-se na hora do ócio à rotina do trabalho industrial serializado e padronizado. 0 espetáculo, proporcionado pela indústria cultural, tornaria os homens apaziguados e dependentes, pois a cultura perdera a distância, não mais permite a ela a negação da realidade e sua transformação. A cultura (Kultur) como arte se constitui como aparência, pois seu objetivo é ser o que não pode ser: algo perfeito num mundo imperfeito.

Já Guy Debord, nos anos 60, ressalta a importância também da reprodução social, do consumo, da sociedade midiática, e a vida cotidiana. A sociedade do espetáculo seria a mercantilização de todos os setores da vida social que ainda não tinham sido apropriados pelo mercado, tais como lazer, desejos e vida cotidiana. " 0 espetáculo é 0 momento em que a mercadoria ocupou totalmente a vida social" (DEBORD, 1997, p.30). No primeiro momento, o capitalismo teria explorado o trabalho e a natureza, definindo 0 trabalhador como um produtor, e, agora, em seu momento espetacular, o capitalismo trataria do consumidor e da criação de seus desejos e necessidades. "À medida que a necessidade se encontra socialmente sonhada, o sonho se torna necessário" (idem, p.19). Não é mais só a instância da indústria cultural, é também aquela em que "o espetáculo não é um conjunto de imagens, mas uma relação social entre pessoas, mediadas por imagens"(idem, p.14).

0 envolvimento dos indivíduos na sociedade seria 0 ato de escolher entre as imagens difusas dirigidas ao consumo. Os meios técnicos reduziriam tudo à contemplação de imagens feitas por outros, e o que é vivido seria afastado na sua representação. 0 verdadeiro apareceria como um momento falso porque 0 mundo estaria na dimensão do espetáculo que passara a ser uma unidade da vida real, em que "o espetáculo reúne o separado, mas o reúne como separado" (idem, p.23). 0pondo-se ao capitalismo que tudo organiza, os situacionistas propunham uma intervenção por meio de situações construídas: "um momento da vida, concretamente e deliberadamente construído pela organização coletiva de um ambiente unitário e de um jogo de acontecimentos" (INTERNATIONNALE, 1958, tradução nossa).

Na avaliação de Manovich (2000, p.171-175), Walter Benjamin ainda considerava a distância espacial entre 0 sujeito da visão e 0 objeto visto como fundamental na percepção humana, pois ela garantia a preservação da aura (única presença da obra de arte como fenômeno da distância) de um objeto e isso afastava o desejo 
de trazer as coisas mais próximas de si como ocorria com as massas. Ao se perder a separação entre a visão e seu objeto, tudo ficava igualmente próximo, resultando na impossibilidade de distinguir entre o real e sua fantasmagoria. Pode-se estender esta observação de Manovich sobre W. Benjamin às abordagens de Adorno, Horkheimer e Debord - "0 espetáculo está em toda parte" (DEBORD, 1997 p.30) -, pois elas têm em comum a suposição de uma percepção mais verdadeira do sujeito garantida pela distância em relação ao objeto de percepção. Nesse sentido, 0 espetáculo, ao tornar as distâncias mais fluidas, seria elemento de indiferenciação entre o mundo real e sua fantasmagoria.

Hoje, a colocação de Debord se depararia com um mundo em que a "transformação revolucionária da vida cotidiana" é ironicamente efetuada pelas novas tecnologias e pela pós-indústria. Construir uma situação para o movimento situacionista seria criar um momento da vida construído pela organização coletiva e por meio de um jogo de acontecimentos. Por essas situações criadas é que as populações urbanas deixariam de ser espectadoras para se tornarem construtoras de seus próprios espaços, o que impediria qualquer tipo de espetacularização. Não que as propostas dos situacionistas deixem de ter vigor, porém 0 consumo se torna hoje no modelo pós-industrial cada vez mais de acontecimentos do que de produtos e representações. Criar situações e derivas que passam a fazer parte das paixões e da vida cotidiana que tornam todos os momentos, do lazer ao trabalho, apropriáveis pelas novas formas de organização da produção. A posiçãa passiva é destituída à medida que a sociedade pós-fordista obriga o exercício contínuo de novos sujeitos, tanto na produção como no consumo, transformando o espectador em sujeito participativo e ativo, além das tecnologias cada vez mais estreitarem a separação entre espectador e ator, público e cena.

Janet Murray (1997) conduz ao extremo essa diluição das fronteiras ao situar no ciberespaço ${ }^{12}$ a imersão no espetáculo: retira do espetáculo seu caráter de falsidade ou ocultação e afasta a distância como lugar crítico. Encontrando este espaço de imersão hoje no mundo da tecnologia, Murray retoma o sentido tradicional do espetáculo como sendo o da descida de um deus ao mundo dos comuns mortais, que pode ser Dionísio nas festas gregas ou Papai Noel circulando na Broadway. 0 espetáculo, nesse sentido, serve para criar exaltação, mover as pessoas para outra ordem de percepção e fixá-las no momento. Através da História, a autora demonstra que 0 espetáculo tenta mover as pessoas em torno de uma narrativa de participação para reter a atenção e estender uma experiência imersiva. Na Idade Média, por 
exemplo, os rituais da Igreja eram estendidos através de uma forma dramática popular em que mistérios e milagres viravam performances em torno da cidade. Esta tradição teria sobrevivido em diversas manifestações, desde as máscaras renascentistas às festas de Halloween norte-americanas. 0 espetáculo adquire aqui sentido positivo, que é concomitantemente mover as pessoas pela atenção para fixá-las na imersão do momento.

\section{Conclusão}

Em seu livro Revoluções do Capitalismo, Lazzarato (2006) caracteriza a publicidade como neutralizadora do acontecimento em dois momentos: ao reduzir a criação de possíveis quando efetua um só possível; e ao fazer o jogo de oposições binárias, incitando o partilhar de determinada maneira de ser, de um mesmo repertório de crenças. A liberdade que ela oferece é a de escolher entre os possíveis que outros instituíram e conceberam. Na verdade, está sendo retirado o espaço para a criação de possíveis que é justamente 0 de um tempo de experimentação e, deste modo, a publicidade faz parte do jogo da sociedade de controle ${ }^{13}$ que se caracteriza pela multiplicação da oferta de mundos possíveis. 0 autor se pergunta: quando publicidade, arte e mercado solicitam um receptor ativo, ao invés do outrora espectador passivo, e criador de narrativas para seus próprios desejos e preferências, assim como incentivam ambíguas sensorialidades e olhares descentralizados por parte de cada espectador, quando é que se encontraria um tempo qualquer de experimentação que não estivesse já contido nesta oferta dos mundos possíveis?

Por sua vez, Jacques Rancière (2008) observa que uma mesma exposição pôde ser apresentada nos Estados Unidos com o título pop "Let's entertain" e em francês com o título "Au-delà du spectacle" (Para além do espetáculo). Segundo ele, em ambos os casos, o que 0 espectador tinha à sua frente eram dispositivos de instalação "imitando" os brinquedos dos parques de diversão, os mangás ou as novelas, os sons das discotecas, etc. Mas, num caso, a etiqueta convidava a participar de uma arte "lúdica", consciente da inexistência de qualquer separação efetiva entre seus elementos e os elementos comerciais que ela imita. No outro, ela convidava a ver na nova contextualização desses elementos, nas formas de apresentação da arte dos museus, uma crítica do mundo espetacular da mercadoria. 0 dispositivo artístico vive, assim, segundo 
Rancière, da indecidibilidade de seu mecanismo e de seu efeito.

Talvez às urgências que 0 dispositivo da publicidade responda não só se encontrem no controle da oferta de experiências possíveis ou na sua indecidibilidade. Ao tornar opacas as fronteiras, a publicidade promove experiências cujo objetivo vai além de torná-las rememoráveis, pois, à medida que são espetáculos, a publicidade oferece um "tempo de experimentação" que atende às necessidades de conectividade entre vida e mercado, ao vincular a população, tornando-a produtiva, fazendo com que cada um que dele participe possa avaliar o movimento do outro e de si mesmo, os elos da vida cotidiana com os momentos de exaltação e de incitamento, participação ativa que evoca sensorialidades multi-comunicacionais e favorece olhares descentralizados, "mover para fixar", de modo que todos podem ser acionados a qualquer momento, no twitter, na praça, na TV, no Youtube, no celular, no Orkut....

\section{Referências}

AGAMBEN, Giorgio. Gloses marginales aux commentaires sur la société du spectacle. Futur Antérieur 2, Paris, eté 1990.

ADORNO, Theodor; HORKHEIMER, Max. Dialética do esclarecimento. Rio de Janeiro: Zahar, 1985

ARVIDSSON, Adam. Brands: meaning and value in media culture. New York: Routledge, 2006.

BENJAMIN, Walter. A obra de arte na época de sua reprodutibilidade técnica. In: . Textos escolhidos. 2.ed. São Paulo: Abril Cultural, 1983. p. 3-38. (Coleção Pensadores)
Experiência e pobreza. In: . Obras escolhidas. São Paulo: Brasiliense, 1985. p. 114-119. v.1.

BRUNS, Axel. Blogs, wikipedia, second life, and beyond: from production to produsage. New York: Lang Publishing, 2008.

DEBORD, Guy. Sociedade do espetáculo. Rio de Janeiro: Contraponto, 1997.

DELEUZE, Gilles. Pourparlers. Paris: Minuit,1990.

ESTRANHOS prazeres (Strange Days). Direção: Kathryn Bigelow. EUA: Universal Pictures, 1995. 145 $\min$.

FOUCAULT, Michael. The confession of the flesh. In: GORDON, Colin. (ed.) Power and knowledge: selected interviews and other writings. New York: Pantheon Books, 1980. p. 194-228.

FOUCAULT, M. Microfísica do poder. 3.ed. Rio de Janeiro: Graal, 1982.

G0RZ, André. 0 imaterial. São Paulo: Annablume, 2005.

KELLER, Kevin L. Building customer-based brand equity. Marketing management, [S.l], v. 10, n. 2, p. 14-19, jul./aug. 2001.

KLEIN, N. Marcas globais e poder corporativo. In. Moraes, Dênis de. (org.) Por uma outra comunicação. Rio de Janeiro: Record, 2003. p. 173 -186.

KOTHE, Flávio (org.). Walter Benjamin. São Paulo: Ática, 1982.

KOTLER, Philip. Administração de marketing. 5 ed. São Paulo: Atlas, 1998.

HARVEY, David. A condição pós-moderna. 5 ed. São Paulo: Loyola, 1992.

INTERNATIONALE Situationniste - numéro 1 - juin 1958. Disponível em: <http://i-situationniste.blogspot. com/2007/04/internationale-situationniste-numero-1. 
html>. Acesso em: 17 ago. 2007.

LAZZARATO, Maurizio. As revoluções do capitalismo.

Rio de Janeiro: Civilização Brasileira, 2006.

MANOVICH, Lev. The language of new media.

Cambridge: MIT Press, 2001

MARAZZI, Christian. A crise da new economy e 0

trabalho das multidões. In:

COCCO, Giuseppe; HOPSTEIN, Graciela. As multidões

e o império. Rio de Janeiro: DP\&A, 2002. p. 31-42.

MURRAY, Janet. Hamlet on the holodeck. New York:

Free Press, 1997.

PINE II, B. Joseph ; GILMORE, James H. Welcome to the experience economy. Harvard business review, Boston, MA. p. 97-105, Jul.-Aug. 1998.

The experience economy. Boston:

Harvard Business School Press, 1999.

PINHEIR0, Marta de Araújo. Redes: um novo projeto político da comunicação. In: COGO, Denise; MAIA, João. (orgs.). Comunicação para a cidadania. Rio de Janeiro: UERJ, 2006. p. 71-84.

Comunicação, consumo e produção de

si. In: COUTINHO, Iluska; MENDES DA SILVEIRA

JR, Potiguara (orgs.). Comunicação: tecnologia e identidade. Rio de Janeiro: Mauad, 2007. p. 51-64.

RABINOW, Paul; ROSE, Nikolas. Thoughts on the concept of biopower today. Disponível em: <http:// www.molsci.org/research/publications_pdf/Rose_ Rabinow_Biopower_Today.pdf $>$. Acesso em: 20 jun. 2004.

RANCIÈRE. J. Política da arte. Disponível em: <www. sescsp.org.br/sesc/images/upload/conferencias>. Acesso em: 15 maio 2008.

0'REILLY, Tim. Web Squared: web 2.0 five years on. In: WEB 2.0 SUMMIT. San Francisco, California, 2009. Disponível em: <www.web2summit.com>. Acesso em: 3 mar. 2009.
ROSE, Nikolas. Governing "advanced"liberal and democracy. In: BARRY, Andrew, OSBORNE, Thomas, ROSE, Nikolas. (eds.). Foucault and political reason. London: Routledge, 1996. p. 37-64.

ROSE, N. Governing "advanced" liberal and democracy. In.: BARRY, André; OSBORNE, Thomas; ROSE, Nikolas. (eds.). Foucault and political reason. London: Routledge, 1996. p. 37-64.

ROSE, Nikolas. Powers of freedon. Cambridge:

Cambridge University Press, 1999.

TUCHERMAN, Ieda; SAINT-CLAIR, Ericson. 0 corpo transparente: dispositivos de visibilidade e mutações do olhar. Intexto, Porto Alegre, v.2, n. 19, p. 1-17, jul.dez. 2008. 


\section{Strange days: publicity and spectacle}

\section{Abstract}

Nowadays, publicity is an apparatus oriented to experiments which have caused an impasse to contemporary culture. As its purpose is to impress the user/consumer with an everlasting sensation, publicity appropriates the spectacle in the sense that it involves the spectator. The hypothesis is that this new use of language depends not only upon the challenges brought up by the new interfaces, by the information excess or by the digital, dispersed and accelerated culture. This use is also due to the postindustrial society claims which create indiscernible zones between everyday life and spectacle, experience and illusion.

\section{Keywords}

Publicity. Spectacle. Experience. Culture.

\section{Días raros: publicidad y espectáculo}

\section{Resumen}

La publicidad es hoy un dispositivo de experiencias que pone obstáculos sin salida para la cultura contemporánea. Al tener como intención echar en el consumidor la sensación que en cualquier momento sea recordada, se apropia del espectáculo en el sentido de envolver el espectador. La hipótesis es la de que el uso del lenguaje no es solamente debido a los desafíos provocados por los nuevos interfaces, por el exceso de información y por la cultura digital acelerada y dispersada. También es debido a las peticiones de la sociedad postindustrial, que crean zonas indiscernibles entre cotidiano y espectáculo, experiencia e ilusión.

\section{Palabras clave}

Publicidad. Espectáculo. Experiencia. Cultura. 


\section{Expediente}

A revista E-Compós é a publicação científica em formato eletrônico da Associação Nacional dos Programas de Pós-Graduação em Comunicação (Compós). Lançada em 2004, tem como principal finalidade difundir a produção acadêmica de pesquisadores da área de Comunicação, inseridos em instituições do Brasil e do exterior.
E-COMPÓS I www.e-compos.org.br I E-ISSN 1808-2599

Revista da Associação Nacional dos Programas de Pós-Graduação em Comunicação. Brasília, v.12, n.3, set./dez. 2009

A identificação das edições, a partir de 2008 passa a ser volume anual com três números.

\section{CONSELHO EDITORIAL}

Afonso Albuquerque

Universidade Federal Fluminense, Brasil

Alberto Carlos Augusto Klein

Universidade Estadual de Londrina, Brasi

Alex Fernando Teixeira Primo

Universidade Federal do Rio Grande do Sul, Brasil

Alfredo Vizeu

Universidade Federal de Pernambuco, Brasi

Ana Carolina Damboriarena Escosteguy

Pontifícia Universidade Católica do Rio Grande do Sul, Brasil

Ana Silvia Lopes Davi Médola

Universidade Estadual Paulista, Brasil

André Luiz Martins Lemos

Universidade Federal da Bahia, Brasil

Ângela Freire Prysthon

Universidade Federal de Pernambuco, Brasil

Antônio Fausto Neto

Universidade do Vale do Rio dos Sinos, Brasil

Antonio Carlos Hohlfeldt

Pontifícia Universidade Católica do Rio Grande do Sul, Brasil

Arlindo Ribeiro Machado

Universidade de São Paulo, Brasil

César Geraldo Guimarães

Universidade Federal de Minas Gerais, Brasi

Cristiane Freitas Gutfreind

Pontifícia Universidade Católica do Rio Grande do Sul, Brasil

Denilson Lopes

Universidade Federal do Rio de Janeiro, Brasil

Eduardo Peñuela Cañizal

Universidade Paulista, Brasil

Erick Felinto de Oliveira

Universidade do Estado do Rio de Janeiro, Brasil

Francisco Menezes Martins

Universidade Tuiuti do Paraná, Brasil

Gelson Santana

Universidade Anhembi/Morumbi, Brasil

Goiamérico Felício

Universidade Federal de Goiás, Brasil

Hector Ospina

Universidad de Manizales, Colômbia

Herom Vargas

Universidade Municipal de São Caetano do Sul, Brasil

leda Tucherman

Universidade Federal do Rio de Janeiro, Brasil

Itania Maria Mota Gomes

Universidade Federal da Bahia, Brasil

Janice Caiafa

Universidade Federal do Rio de Janeiro, Brasil

Jeder Silveira Janotti Junior

Universidade Federal da Bahia, Brasil

\section{João Freire Filho}

Universidade Federal do Rio de Janeiro, Brasil

John DH Downing

University of Texas at Austin, Estados Unidos

José Luiz Aidar Prado

Pontifícia Universidade Católica de São Paulo, Brasil

José Luiz Warren Jardim Gomes Braga

Universidade do Vale do Rio dos Sinos, Brasi

Juremir Machado da Silva

Pontifícia Universidade Católica do Rio Grande do Sul, Brasil

Lorraine Leu

University of Bristol, Grã-Bretanha

Luiz Claudio Martino

Universidade de Brasília, Brasil

Maria Immacolata Vassallo de Lopes

Universidade de São Paulo, Brasil

Maria Lucia Santaella

Pontifícia Universidade Católica de São Paulo, Brasil

Mauro Pereira Porto

Tulane University, Estados Unidos

Muniz Sodre de Araujo Cabral

Universidade Federal do Rio de Janeiro, Brasil

Nilda Aparecida Jacks

Universidade Federal do Rio Grande do Sul, Brasil

Paulo Roberto Gibaldi Vaz

Universidade Federal do Rio de Janeiro, Brasil

Renato Cordeiro Gomes

Pontifícia Universidade Católica do Rio de Janeiro, Brasil

Ronaldo George Helal

Universidade do Estado do Rio de Janeiro, Brasil

Rosana de Lima Soares

Universidade de São Paulo, Brasil

Rossana Reguillo

Instituto Tecnológico y de Estudios Superiores do Occidente, México

Rousiley Celi Moreira Maia

Universidade Federal de Minas Gerais, Brasil

Samuel Paiva

Universidade Federal de São Carlos, Brasil

Sebastião Albano

Universidade Federal do Rio Grande do Norte, Brasil

Sebastião Carlos de Morais Squirra

Universidade Metodista de São Paulo, Brasil

Simone Maria Andrade Pereira de Sá

Universidade Federal Fluminense, Brasi

Suzete Venturelli

Universidade de Brasília, Brasil

Valério Cruz Brittos

Universidade do Vale do Rio dos Sinos, Brasil

Veneza Mayora Ronsini

Universidade Federal de Santa Maria, Brasil

Vera Regina Veiga França

Universidade Federal de Minas Gerais, Brasi

\section{COMISSÃO EDITORIAL}

Felipe da Costa Trotta I Universidade Federal de Pernambuco, Brasil Rose Melo Rocha I Escola Superior de Propaganda e Marketing, Brasil

\section{CONSULTORES AD HOC}

Arthur Autran Franco de Sá Neto I Universidade Federal de São Carlos

Carlos Eduardo Franciscato I Universidade Federal de Sergipe

Elisa Reinhardt Piedras I Universidade Federal do Rio Grande do Sul

Elizabeth Bastos Duarte I Universidade Federal de Santa Maria

Marcia Benetti Machado I Universidade Federal do Rio Grande do Sul

Sandra Maria Lúcia Pereira Gonçalves I Universidade Federal do Rio Grande do Sul

Suzana Kilpp I Universidade do Vale do Rio dos Sinos

Tattiana Gonçalves Teixeira I Universidade Federal de Santa Catarina

Vander Casaqui I Escola Superior de Propaganda e Marketing

Vicente Gosciola I Universidade Anhembi Morumb

Walter Teixeira Lima Junior I Fundação Cásper Líbero

REVISÃO DE TEXTO E TRADUÇÃO I Everton Cardoso

EDITORAÇÃO ELETRÔNICA I Raquel Castedo
COMPóS I www.compos.org.br

Associação Nacional dos Programas de Pós-Graduação em Comunicação

Presidente

Itania Maria Mota Gomes

Universidade Federal da Bahia, Brasil

itania@ufba.br

Vice-presidente

Julio Pinto

Pontifícia Universidade Católica de Minas Gerais, Brasil

juliopinto@pucminas.br

Secretária-Geral

Ana Carolina Escosteguy

Pontifícia Universidade Católica do Rio Grande do Sul, Brasil

carolad@pucrs.br 